\title{
SYNTHESIS AND DNA INTERACTION OF A Sm(III) COMPLEX OF A SCHIFF BASE DERIVED FROM VANILLIN AND L-TRYPTOPHAN
}

\author{
Xing-ming Wang $^{1 *}$, Yan Zhang ${ }^{1}$, Ting-ting Zhao ${ }^{1}$ and Li-sheng Ding ${ }^{2}$ \\ ${ }^{1}$ Department of Chemistry, School of Materials Science and Engineering, Southwest University \\ of Science and Technology, Mianyang 621010, China \\ ${ }^{2}$ Chengdu Institute of Biology, Chinese Academy of Sciences, Chengdu 610041, China
}

(Received July 7, 2010; revised January 4, 2011)

\begin{abstract}
The interaction between the Sm(III) complex of an ionic Schiff base [HL] $]^{-}$, derived from vanillin and L-tryptophan, and herring sperm DNA at physiological pH (7.40) has been studied by UV-Vis absorption, fluorescence and viscosity methods. The binding ratios $n_{\mathrm{Sm}(\mathrm{III})}: n_{\mathrm{K}[\mathrm{HL}]}=1: 1$ and $n_{\mathrm{Sm}(\mathrm{III}) \mathrm{L}:} n_{\mathrm{DNA}}=5: 1$ were confirmed by a mole ratio method. The calculated binding constants of [Sm(III)L $]^{+}$with DNA at 25 and $37^{\circ} \mathrm{C}$ were $1.19 \times 10^{5} \mathrm{M}^{-1}$ and $3.96 \times 10^{4} \mathrm{M}^{-1}$, respectively. The thermodynamic parameters demonstrate that the interaction between $[\mathrm{Sm}(\mathrm{III}) \mathrm{L}]^{+}$and $\mathrm{DNA}$ is driven mainly by enthalpy. Fluorimetric studies show that $[\mathrm{Sm}(\mathrm{III}) \mathrm{L}]^{+}$is able to displace intercalated acridine orange. Combined with Scatchard methods, circular dichroism spectroscopy and viscosity measurements, the results indicate that the interaction between $[\mathrm{Sm}(\mathrm{III}) \mathrm{L}]^{+}$and herring sperm DNA is mainly by intercalation with some groove binding.
\end{abstract}

KEY WORDS: Vanillin, L-Tryptophan, Sm(III) complex of Schiff base, Herring sperm DNA, Interaction

\section{INTRODUCTION}

DNA is the primary intracellular target of anticancer reagents because interaction between metal complexes and DNA can cause damage in cancer cells, blocking cell division [1,2]. To date, much attention has been paid to binding of metal complexes containing multidentate aromatic ligands. Generally, these complexes bind to DNA by a series of non-covalent interactions, such as intercalation, electrostatic and groove binding [3, 4]. Many molecules show more than one interaction mode with DNA, depending on structural features of both the molecule and the DNA [5].

A Schiff base is obtained by the condensation between an aldehyde and an amine [6]. Complexes with transition metals are considered to be new kinds of anticancer and antiviral reagents, because of their range of biological and pharmaceutical effects, such as anticancer, antitumor and antioxidative activities as well as inhibition of lipid peroxidation [7-9].

L-Tryptophan (Trp) is an essential amino acid that is required for the biosynthesis of proteins and is important in nitrogen balance and the maintenance of muscle mass and body weight in humans [10]. The rare earth metals have wide applications in medicine. They are superior to transition metals and their complexes because they can bind to nucleic acids more efficiently [11]. Coordination with ligands reduces and can enhance physiological activity.

${ }^{153} \mathrm{Sm}$ is used in treatment of severe pain associated with bone cancers and $\mathrm{Sm}$ compounds are also used in rare earth antiphlogistic sterilization drugs.

We have studied the interaction between a tryptophan-vanillin Schiff base and herring sperm DNA, and found evidence for intercalation and groove binding [12]. In this paper, we describe the synthesis of a $\mathrm{Sm}$ (III) complex with the Schiff base and the determination of a series of thermodynamic parameters and binding constants for the interaction of this complex with DNA.

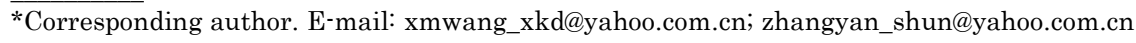


Apparatus

\section{EXPERIMENTAL}

Carbon, hydrogen and nitrogen analyses were obtained by use of a Vario EL CUBE (Germany). IR spectra $\left(400-4000 \mathrm{~cm}^{-1}\right)$ were recorded as $\mathrm{KBr}$ pellets on a Spectrum One FTIR system (USA). Absorption spectra were measured on an UV-210 spectrophotometer (Japan) and fluorescence spectra on a FL-4500 spectrofluorophotometer (Japan). Circular dichroism (CD) measurements were recorded on a Jasco-815 spectropolarimeter (Japan). The $\mathrm{pH}$ was recorded on a pHS-2C digital pH-meter (China) with a combined glass-calomel electrode.

\section{Materials}

Herring Sperm DNA (hsDNA) was purchased from Sigma Biological Co. (USA) and used as received. The purity of the DNA was checked by monitoring the ratio of absorbance at 260 to that at $280 \mathrm{~nm}$. The ratio $A_{260} / A_{280}$ was 1.89 , indicating that DNA was free from protein [13]. The DNA was dissolved in doubly distilled deionized water with $50 \mathrm{mM} \mathrm{NaCl}$ and dialyzed for $48 \mathrm{~h}$ against a buffer solution at $4{ }^{\circ} \mathrm{C}$. The concentration of hsDNA stock solution was determined by UV absorbance at $260 \mathrm{~nm}$ using a molar absorption coefficient $\varepsilon=6600 \mathrm{M}^{-1} . \mathrm{cm}^{-1}$ [13].

A tris(hydroxymethyl)aminomethane- $\mathrm{HCl}$ buffer $(0.05 \mathrm{M}, \mathrm{pH} 7.40)$, was used to control the pH. $\mathrm{Sm}_{2} \mathrm{O}_{3}$, obtained from Beijing Fangzheng Rare Metal Lab Company (99.99 \%) (China), was dissolved in conc. $\mathrm{HCl}$, then water and excess $\mathrm{HCl}$ were evaporated slowly to give a white powder that was added to tris- $\mathrm{HCl}$ buffer to prepare known concentrations of $\mathrm{SmCl}_{3}$. LTryptophan was purchased from Chengdu-China Kelong Chemical Plant (A.R.) (China). Vanillin was purchased from Xian-China Chemical Plant (A.R.) (China). Acridine orange (AO) was purchased from Shanghai-China Medicine Chemical Plant (A.R.) (China). Other reagents were at least analytical grade, and were used without further purification.

Procedures

Preparation of the potassium salt K[HL] and the Sm(III) complex $S m L C l$

The Schiff base (K[HL]) derived from vanillin and L-tryptophan was prepared using a method similar to that in the literature [14]. To a solution of vanillin $(0.180 \mathrm{~g}, 1.2 \mathrm{mmol})$ in $\mathrm{MeOH}(10$ $\mathrm{mL})$, L-tryptophan $(0.204 \mathrm{~g}, 1 \mathrm{mmol})$ in $\mathrm{MeOH}(15 \mathrm{~mL})$ containing $\mathrm{KOH}(0.056 \mathrm{~g}, 1 \mathrm{mmol})$ was added. The solution was then magnetically stirred for $5 \mathrm{~h}$ at $50-60{ }^{\circ} \mathrm{C}$ on a water bath. The volume of brownish red solution was reduced in vacuo using rotary evaporator to about $5 \mathrm{~mL}$. Then absolute ethanol was added to the solution to precipitate the solid. After several days a black product was separated, washed with $\mathrm{Et}_{2} \mathrm{O}$ and dried in vacuo. From the IR spectrum and elemental analysis, the structure of $\mathrm{K}[\mathrm{HL}]\left(\mathrm{C}_{19} \mathrm{H}_{17} \mathrm{~N}_{2} \mathrm{O}_{4} \mathrm{~K} \cdot 2 \mathrm{H}_{2} \mathrm{O}\right)$ is proposed in Scheme 1 [12].

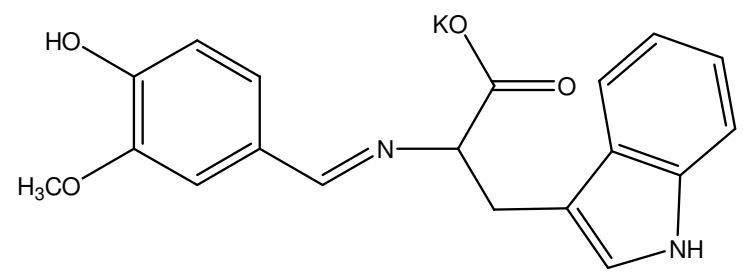

Scheme 1. The proposed structure of the Schiff base K[HL]. 
$\mathrm{SmCl}_{3}(0.5 \mathrm{mmol})$ was dissolved in $\mathrm{MeOH}(10 \mathrm{~mL})$ and the solution was added dropwise to a methanolic solution of $\mathrm{K}[\mathrm{HL}](15 \mathrm{~mL}, 0.5 \mathrm{mmol})$. The mixture was stirred magnetically for 2 $\mathrm{h}$ at $50-60{ }^{\circ} \mathrm{C}$. The volume of the solution was reduced to $10 \mathrm{~mL}$ in a rotary evaporator. After several days the brown product was washed with $\mathrm{EtOH}$ then $\mathrm{Et}_{2} \mathrm{O}$ and dried in vacuo.

\section{Absorption spectral measurements}

$3.0 \mathrm{~mL}$ samples, in $1.0 \mathrm{~cm}$ quartz cells, were titrated by a stock solution of $\mathrm{SmCl}_{3}$. Similarly 3.0 $\mathrm{mL}$ samples of $\mathrm{Sm}(\mathrm{III}) \mathrm{L}$ solution in $1.0 \mathrm{~cm}$ quartz cells were titrated with a stock solution of DNA. The titration was done manually by use of a micro-injector and incremental addition injection of $10 \mu \mathrm{L}$ samples to minimise changes of volume. Appropriate blanks corresponding to the buffer were used as reference. The absorption spectra were measured after $5 \mathrm{~min}$.

\section{Fluorescence spectral measurements}

$3.0 \mathrm{~mL}$ samples of $\mathrm{Sm}(\mathrm{III})$-DNA in $1.0 \mathrm{~cm}$ quartz cells, were titrated with a stock solution of AO and $3.0 \mathrm{~mL}$ samples of AO-DNA were titrated by a stock solution of Sm(III)L. Each injection was $10 \mu \mathrm{L}$ to avoid change of volume. The widths of both the excitation slit and the emission slit were set at $5.0 \mathrm{~nm}$; and the excitation wavelength was set at $411.7 \mathrm{~nm}$. The fluorescence spectra were measured after $5 \mathrm{~min}$.

\section{Circular dichroism $(C D)$ measurements}

Circular dichroism (CD) measurements were made at room temperature on a Jasco-815 spectrophotometer, with $1 \mathrm{~cm}$ quartz cells and recorded in the range $200-450 \mathrm{~nm}$ with a scan rate of $50 \mathrm{~nm} \cdot \mathrm{min}^{-1}$.

\section{Viscosity measurements}

Viscosity experiments were made at room temperature. Various amounts of Sm(III)L was then added to a solution of DNA in the viscometer to give increasing values of $c_{\mathrm{Sm}(\mathrm{III})}$ while keeping the DNA concentration constant. The flow times of the samples were repeatedly measured with an accuracy of $\pm 0.2 \mathrm{~s}$ by a digital stopwatch. Each point was the average of at least three measurements. The buffer flow time $\left(t_{0}\right)$ was observed, and relative viscosities for DNA in the presence and absence of $\mathrm{Sm}$ (III)L were calculated from the relation $\eta=\left(t-t_{0}\right) / t_{0}$, where $t$ is the observed flow time. The data were presented as plots of $\left(\eta / \eta_{0}\right)^{1 / 3}$ versus $c_{\mathrm{Sm}(\mathrm{III}) \mathrm{L}}$, where $\eta$ and $\eta_{0}$ are the viscosity of DNA in the presence and absence of $\mathrm{Sm}(\mathrm{III}) \mathrm{L}$, respectively.

\section{RESULTS AND DISCUSSION}

Interaction between $\mathrm{Sm}(\mathrm{III})$ and $\mathrm{K}[H L]$

The UV-Vis spectra of K[HL] show three transitions: two at 213 and $280 \mathrm{~nm}$; and one at 340 $\mathrm{nm}$. The stoichiometry of the interaction of Sm(III) with K[HL] was determined by the mole ratio method [15] at $280 \mathrm{~nm}$. The mole ratio plots of $\mathrm{Sm}(\mathrm{III})$ vs K[HL] is shown in Figure 1. The binding ratio of the complex: $n_{\mathrm{Sm}(\mathrm{III})}: n_{\mathrm{K}[\mathrm{HL}]}$ was $1: 1$.

The IR spectral data of K[HL] and the complex Sm(III)L are given in Table 1. The strong band at $1627 \mathrm{~cm}^{-1}$ can be assigned to the $v(\mathrm{C}=\mathrm{N})$ azomethine stretching vibration. On complexation, this band shifts to higher frequency at $1633 \mathrm{~cm}^{-1}$ indicating the coordination of the azomethine nitrogen atom to the central metal ion [16]. The peaks assigned to carboxyl stretching $v_{\text {asym }}\left(\mathrm{COO}^{-}\right)$and $v_{\text {sym }}\left(\mathrm{COO}^{-}\right)$are shifted to 1601 and $1354 \mathrm{~cm}^{-1}$, respectively, 
indicating the linkage between the metal ion and carboxylato oxygen atom [16, 17]. The phenolic $v(\mathrm{C}-\mathrm{O})$ band was shifted to lower frequency at $1263 \mathrm{~cm}^{-1}$ indicating the coordination of the phenolic oxygen atom to the metal ion [16]. In the low frequency region, the band at 523 $\mathrm{cm}^{-1}$ is assigned to $v(\mathrm{M}-\mathrm{N})$ and the band at $466 \mathrm{~cm}^{-1}$ to $v(\mathrm{M}-\mathrm{O})$ [17-20]. The broad band at 3429 $\mathrm{cm}^{-1}$ indicates that water is present in the Schiff base, which is coordinated to the central through phenolic oxygen, imino nitrogen and carboxylato oxygen atoms. Anal. cal. for $\left[\mathrm{Sm}(\mathrm{III}) \mathrm{C}_{19} \mathrm{H}_{16} \mathrm{~N}_{2} \mathrm{O}_{4}\left(\mathrm{H}_{2} \mathrm{O}\right)_{3}\right] \mathrm{Cl} \cdot 2 \mathrm{H}_{2} \mathrm{O}: \mathrm{C}, 37.27 ; \mathrm{H}, 2.78 ; \mathrm{N}, 4.58 \%$. Found: C, 35.43; H, 2.72; N, $4.43 \%$. The proposed structure of the complex Sm(III)L is shown in Scheme 2.

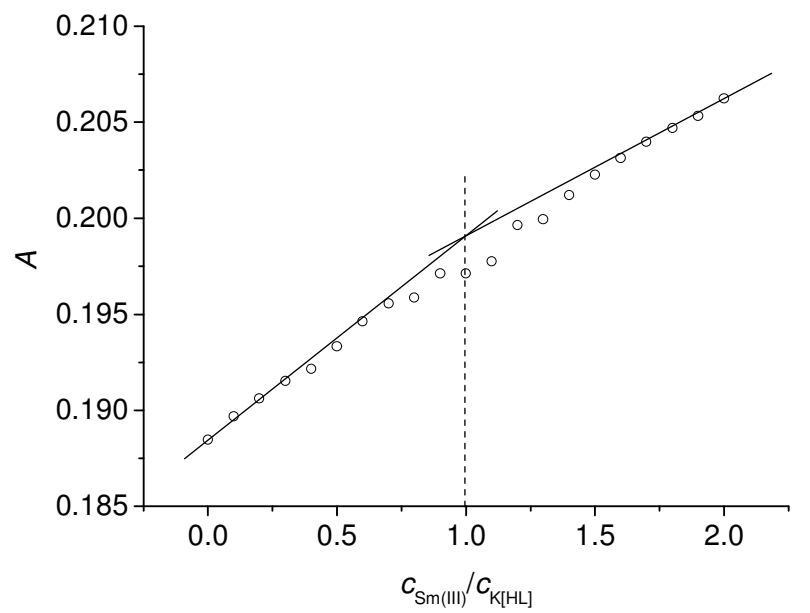

Figure 1. Mole ratio plots of $\mathrm{Sm}(\mathrm{III})-\mathrm{K}[\mathrm{HL}]$ in a tris- $\mathrm{HCl}$ buffer $(\mathrm{pH} 7.40) ; c_{\mathrm{K}[\mathrm{HL}]}=2.00 \times 10^{-5}$ $\mathrm{M}, \lambda=280 \mathrm{~nm}$.

Table 1. Infrared spectral data of Schiff base ligand and its Sm(III) complex $\left(\mathrm{cm}^{-1}\right)$.

\begin{tabular}{|l|c|c|c|c|c|c|}
\hline Compound & $v(\mathrm{O}-\mathrm{H})$ & $v(\mathrm{C}=\mathrm{N})$ & $v_{\text {asym }}\left(\mathrm{COO}^{-}\right)$ & $v_{\text {sym }}\left(\mathrm{COO}^{-}\right)$ & $v(\mathrm{M}-\mathrm{N})$ & $v(\mathrm{M}-\mathrm{O})$ \\
\hline $\mathrm{K}[\mathrm{HL}] \cdot 2 \mathrm{H}_{2} \mathrm{O}$ & 3398 & 1627 & 1593 & 1390 & - & - \\
\hline $\mathrm{Sm}(\mathrm{III}) \mathrm{L}\left(\mathrm{H}_{2} \mathrm{O}\right)_{3} \mathrm{Cl} \cdot 2 \mathrm{H}_{2} \mathrm{O}$ & 3429 & 1633 & 1601 & 1354 & 523 & 466 \\
\hline
\end{tabular}

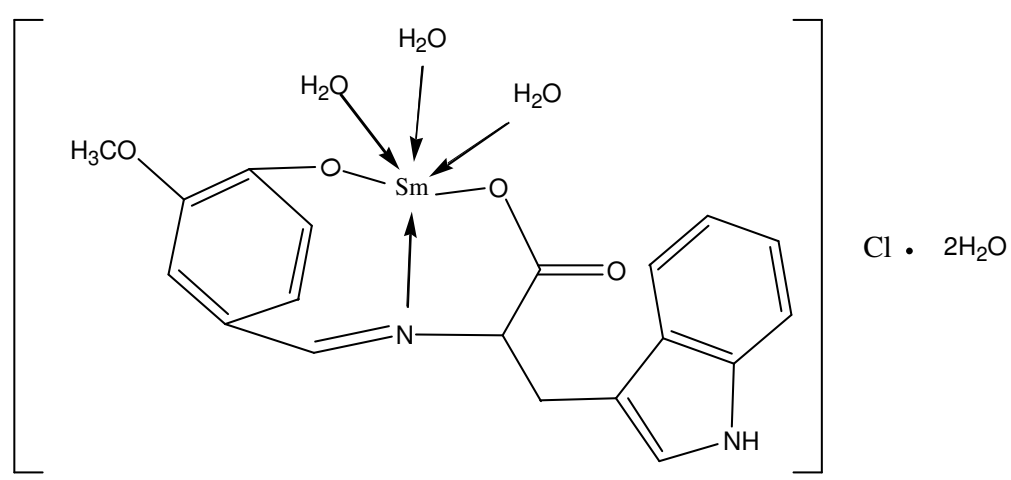

Scheme 2. The proposed structure of the complex $\mathrm{Sm}(\mathrm{III}) \mathrm{L}$.

Bull. Chem. Soc. Ethiop. 2011, 25(2) 
Binding of Sm(III)L complex to DNA

The binding of small molecules to DNA has been characterized classically through absorption titrations [21]. Both red (hypochromic) and blue (hyperchromic) shifts are observed.

UV-Vis absorption spectra were obtained by titration of a solution of Sm(III)L with DNA (Figure 2). In the absence of DNA, the spectrum of Sm(III)L shows three peaks: at 213, 279 and $340 \mathrm{~nm}$. With the addition of DNA, the intensities of the peaks at $213 \mathrm{~nm}$ and $279 \mathrm{~nm}$ absorbance increased, but that at $340 \mathrm{~nm}$ decreased. An isochromatic point was observed at 333 $\mathrm{nm}$. These results indicate the presence of intercalation between Sm(III)L and DNA.

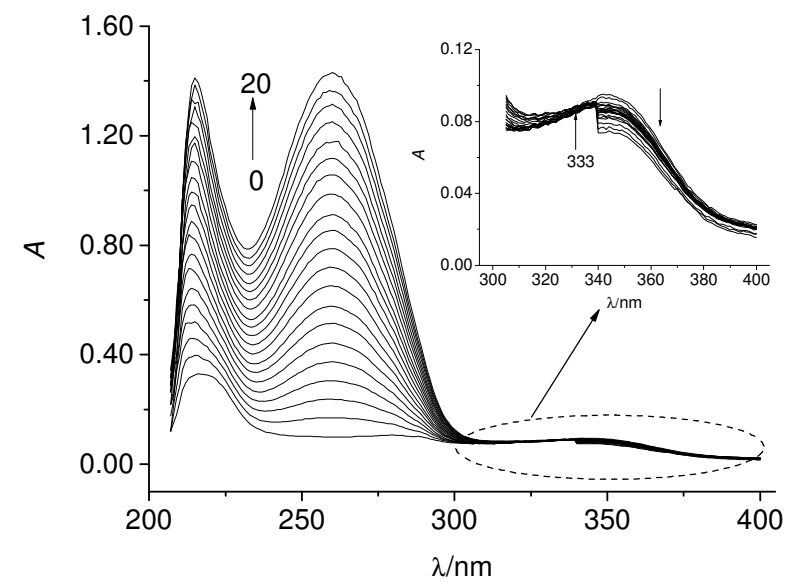

Figure 2. Absorption spectra of $\mathrm{Sm}(\mathrm{III}) \mathrm{L}$ with various molar amounts of DNA (pH 7.40) at 25 ${ }^{\circ} \mathrm{C}$; from curve $0-20, c_{\mathrm{Sm}(\mathrm{III}) \mathrm{L}}=1.00 \times 10^{-5} \mathrm{M}, c_{\mathrm{DNA}}=0.00,0.02,0.04,0.06,0.08,0.10$, $0.12,0.14,0.16,0.18,0.20,0.22,0.24,0.26,0.28,0.30,0.32,0.34,0.36,0.38$ and $0.40 \times 10^{-5} \mathrm{M}$.

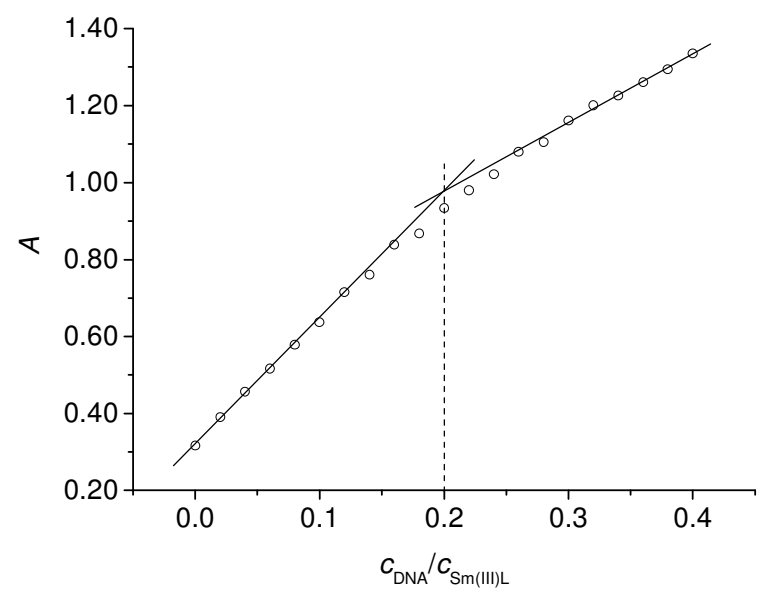

Figure 3. Mole ratio plots of $\mathrm{Sm}(\mathrm{III}) \mathrm{L}-\mathrm{DNA}$ in a tris- $\mathrm{HCl}$ buffer $(\mathrm{pH} 7.40)$ at $25{ }^{\circ} \mathrm{C}$; $c_{\mathrm{Sm}(\mathrm{III}) \mathrm{L}}=1.00 \times 10^{-5} \mathrm{M}, \lambda=213 \mathrm{~nm}$.

Bull. Chem. Soc. Ethiop. 2011, 25(2) 
In order to determine the stoichiometry of the formation of the Sm(III)L-DNA complex, the mole ratio experiment [15] was applied to the peak $213 \mathrm{~nm}$ (Figure 3). The binding ratio of the complex $n_{\mathrm{Sm}(\mathrm{III}) \mathrm{L}}: n_{\mathrm{DNA}}$ was $=5: 1$. The apparent molar absorption coefficient of Sm(III)L-DNA $\varepsilon$ was $4.81 \times 10^{5} \mathrm{M}^{-1} \cdot \mathrm{cm}^{-1}$.

Thermodynamic parameters

The binding constant of Sm(III)L with DNA was determined using the following relationship [22-23]:

$$
1 /\left(A_{0}-A\right)=1 / A_{0}+1 /\left(K \times A_{0} \times c_{\mathrm{DNA}}\right)
$$

where $A_{0}$ and $A$ are the absorbance of $\mathrm{Sm}(\mathrm{III}) \mathrm{L}$ in the absence and in the presence of DNA, respectively. $K$ is the binding constant between $\mathrm{Sm}(\mathrm{III}) \mathrm{L}$ and DNA and $c_{\mathrm{DNA}}$ refers to the concentration of DNA. The plots of $1 /\left(A_{0}-A\right)$ versus $1 / c_{\text {DNA }}$ were linear at 25 and $37{ }^{\circ} \mathrm{C}$ and the binding constants derived from the slope were calculated (Figure 4): $K_{\mathrm{B}}{ }^{\ominus}{ }_{25}=1.19 \times 10^{5} \mathrm{M}^{-1}$, $K_{\mathrm{B}}{ }^{\ominus}{ }_{37}=3.96 \times 10^{4} \mathrm{M}^{-1}$.

The thermodynamic parameters show the binding mode [24]. If the binding enthalpy change $(\Delta H)$ is invariant over a small temperature range [25] the standard molar binding enthalpy $\left(\Delta H_{\mathrm{m}}{ }^{\ominus}\right)$, is estimated from the relationship:

$$
\ln K_{2}{ }^{\Theta} / K_{1}{ }^{\ominus}=-\Delta_{\mathrm{r}} H_{\mathrm{m}}{ }^{\ominus}\left(1 / T_{2}-1 / T_{1}\right) / R
$$

where $K_{1}{ }^{\ominus}$ and $K_{2}{ }^{\ominus}$ are the standard binding constants of Sm(III)L and DNA at 25 and $37{ }^{\circ} \mathrm{C}$, respectively. Then $\Delta H_{\mathrm{m}}{ }^{\ominus}$ is $-6.93 \times 10^{5} \mathrm{~J} \cdot \mathrm{mol}^{-1}$ : the binding of Sm(III)L to DNA is exothermic. From this and the value of the equilibrium constant: $\Delta G_{\mathrm{m}}{ }^{\Theta}$ is calculated as $-2.90 \times 10^{4} \mathrm{~J} \cdot \mathrm{mol}^{-1}$ and $\Delta S_{m}{ }^{\Theta}$ is $-2.23 \times 10^{3} \mathrm{~J} \cdot \mathrm{mol}^{-1} \cdot \mathrm{K}^{-1}$. The negative value of $\Delta G_{\mathrm{m}}{ }^{\ominus}$ is consistent with a spontaneous process, and the negative values of $\Delta H_{m}{ }^{\ominus}$ and $\Delta S_{\mathrm{m}}{ }^{\ominus}$ indicate that the binding is mainly enthalpy driven.

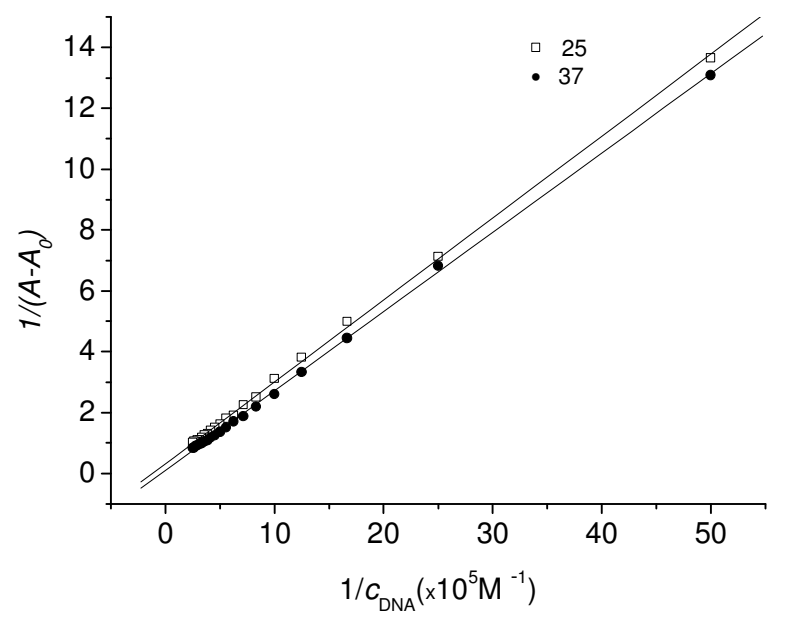

Figure 4. Double reciprocal plots of Sm(III)L-DNA in a tris-HCl buffer at 25 and $37{ }^{\circ} \mathrm{C}$, respectively $(\mathrm{pH} 7.40) ; c_{\mathrm{Sm}(\mathrm{III}) \mathrm{L}}=1.00 \times 10^{-5} \mathrm{M}$. 
Fluorescence measurements with acridine orange $(A O)$ as probe

Since the fluorescence of the $\mathrm{Sm}$ (III)L complex is weak both in the presence and absence of DNA, the above results were supplemented by competitive AO binding studies. Because of its planar aromatic chromophore, AO can insert between two adjacent base pairs in a DNA helix.

The emission spectra of Sm(III)L bound to DNA in the absence and the presence of AO are given in Figure 5. There is a significant increase in the fluorescence intensity and a red shift $\Delta \lambda$ of $4 \mathrm{~nm}$ as the $\mathrm{AO}$ inserts between the base pairs.

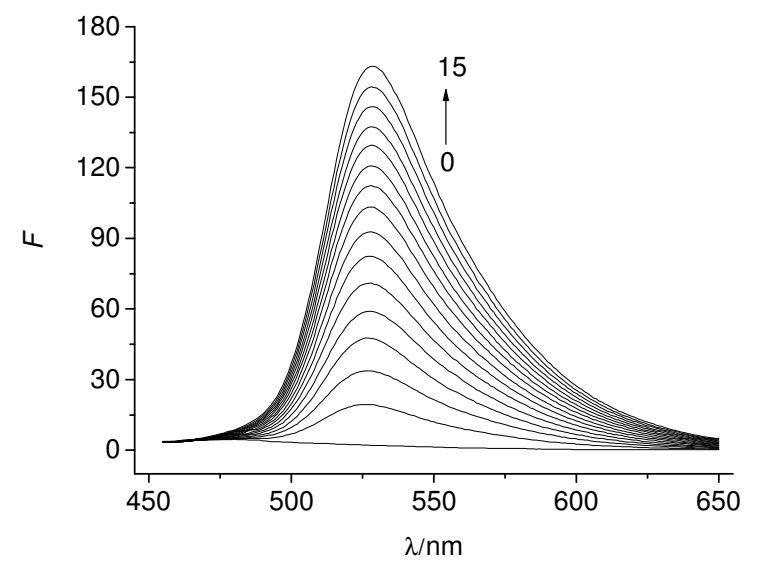

Figure 5. Emission spectra of Sm(III)L-DNA with various concentrations of $\mathrm{AO}\left(\mathrm{pH} 7.40 ; \lambda_{\mathrm{ex}}=\right.$ $411.7 \mathrm{~nm}$ ); from curve $0-15, c_{\mathrm{DNA}}=2.00 \times 10^{-6} \mathrm{M}, c_{\mathrm{AO}}=0.00,0.02,0.04,0.06,0.08$, $0.10,0.12,0.14,0.16,0.18,0.20,0.22,0.24,0.26,0.28$, and $0.30 \times 10^{-5} \mathrm{M}$.

The emission spectra of AO bound to DNA in the absence and the presence of Sm(III)L are given in Figure 6. If $\mathrm{Sm}(\mathrm{III}) \mathrm{L}$ has the same binding mode with DNA as AO, competition between AO and complex would be shown by a change in the fluorescence spectrum [26]. Figure 6, shows that the fluorescence of DNA-AO is efficiently quenched, suggesting that $\mathrm{Sm}(\mathrm{III}) \mathrm{L}$ substitutes for AO i.e. that $\mathrm{Sm}(\mathrm{III}) \mathrm{L}$ intercalates into DNA, consistent with the results above [27].

\section{Scatchard method}

Data for binding studies were processed by the Scatchard procedure [28]. The binding of AO to DNA is expressed using the following equation:

$$
r_{\mathrm{AO}} / c_{\mathrm{AO}}=K\left(n-r_{\mathrm{AO}}\right)
$$

where $r_{\mathrm{AO}}$ is the number of moles of $\mathrm{AO}$ bound per mole of DNA, $c_{\mathrm{AO}}$ is the molar concentration of free AO, $n$ is the number of binding sites per DNA and $K$ is the intrinsic association constant. If $\mathrm{Sm}(\mathrm{III}) \mathrm{L}$ interacts with DNA by intercalation, the intercept on the abscissa $(n)$ should remain constant as the slope $(K)$ changes in the Scatchard plots. If $\mathrm{Sm}(\mathrm{III}) \mathrm{L}$ interacts with DNA by groove or electrostatic binding, $K$ should remain constant as $n$ changes. If the binding mode is mixed, both $n$ and $K$ should change in the Scatchard plots [29].

Various $\mathrm{Sm}(\mathrm{III}) \mathrm{L} / \mathrm{DNA}$ mole ratios $c_{\mathrm{Sm}(\mathrm{III}) \mathrm{L}} / c_{\mathrm{DNA}}=0.00,0.30,0.60,0.90$ were used. Further, experiments without or with addition of $\mathrm{NaCl}$ were compared. $\mathrm{NaCl}$ is not an anionic quencher 
of DNA [30], so its influence on the Sm(III)L-AO-DNA system comes only from ionic strength. Results are shown in Table 2.

It is seen that both $n$ and $K$ change as the concentration of $\mathrm{Sm}(\mathrm{III}) \mathrm{L}$ is increased suggesting that $\mathrm{Sm}(\mathrm{III}) \mathrm{L}$ interacts with DNA by a mixed binding mode. Moreover $n$ is increased by addition of $\mathrm{NaCl}$. Generally, $n$ is reduced in the presence of $\mathrm{NaCl}$, by electrostatic interaction [31], so the interaction is by groove binding rather than electrostatic.

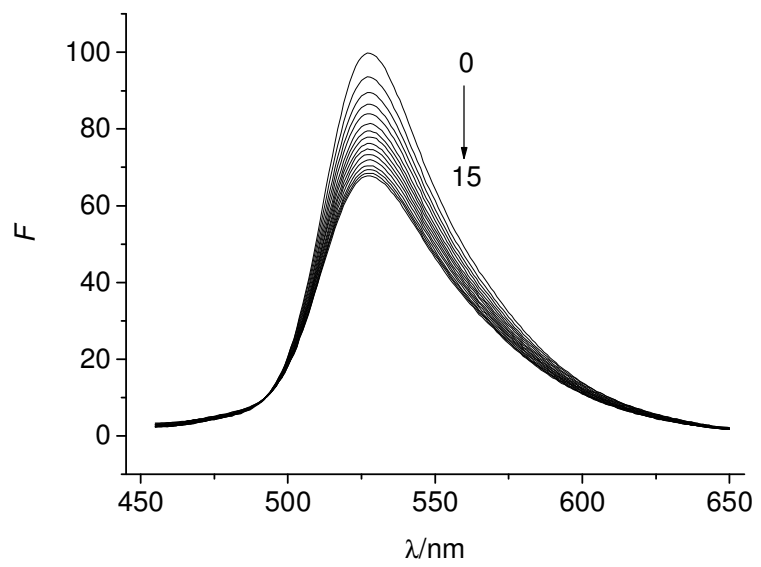

Figure 6. Emission spectra of DNA-AO with various concentrations of Sm(III)L (pH 7.40; $\lambda_{\mathrm{ex}}=$ $411.7 \mathrm{~nm}$ ); from curve $0-15, c_{\mathrm{DNA}-\mathrm{AO}}=1.34 \times 10^{-6} \mathrm{M}, c_{\mathrm{Sm}(\mathrm{III}) \mathrm{L}}=0.00,0.67,1.33,2.00$, $2.67,3.33,4.00,4.67,5.33,6.00,6.67,7.33,8.00,8.67,9.33$, and $10.00 \times 10^{-6} \mathrm{M}$.

Table 2. Data of Scatchard equation of the interaction between Sm(III)L and DNA.

\begin{tabular}{|c|c|c|c|c|c|}
\hline Curve & $\mathrm{Rt}$ & $\mathrm{NaCl} \%$ & Scatchard & $K /\left(\mathrm{M}^{-1}\right)$ & $n$ \\
\hline \multirow{2}{*}{$\mathrm{a}$} & \multirow{2}{*}{0.00} & 5.00 & $2.61 \times 10^{5}-1.56 \times 10^{7} r_{\mathrm{AO}}$ & $1.56 \times 10^{7}$ & 0.0168 \\
\cline { 3 - 7 } & & 0 & $3.21 \times 10^{5}-2.63 \times 10^{7} r_{\mathrm{AO}}$ & $2.63 \times 10^{7}$ & 0.0122 \\
\hline \multirow{2}{*}{$\mathrm{b}$} & \multirow{2}{*}{0.30} & 5.00 & $2.42 \times 10^{5}-1.07 \times 10^{7} r_{\mathrm{AO}}$ & $1.07 \times 10^{7}$ & 0.0226 \\
\cline { 3 - 6 } & & 0 & $1.43 \times 10^{5}-8.08 \times 10^{6} r_{\mathrm{AO}}$ & $8.08 \times 10^{6}$ & 0.0178 \\
\hline \multirow{2}{*}{$\mathrm{c}$} & \multirow{2}{*}{0.60} & 5.00 & $2.79 \times 10^{5}-1.01 \times 10^{7} r_{\mathrm{AO}}$ & $1.01 \times 10^{7}$ & 0.0276 \\
\cline { 3 - 6 } & & 0 & $2.14 \times 10^{5}-9.60 \times 10^{6} r_{\mathrm{AO}}$ & $9.60 \times 10^{6}$ & 0.0224 \\
\hline \multirow{2}{*}{$\mathrm{d}$} & \multirow{2}{*}{0.90} & 5.00 & $3.97 \times 10^{5}-1.17 \times 10^{7} r_{\mathrm{AO}}$ & $1.17 \times 10^{7}$ & 0.0339 \\
\cline { 3 - 7 } & & 0 & $1.95 \times 10^{5}-5.97 \times 10^{6} r_{\mathrm{AO}}$ & $5.97 \times 10^{6}$ & 0.0327 \\
\hline
\end{tabular}

$\mathrm{Rt}=c_{\mathrm{Sm}(\mathrm{III})} / c_{\mathrm{DNA}} ; c_{\mathrm{DNA}}=1.00 \times 10^{-6} \mathrm{M} ; c_{\mathrm{AO}}=3.00 \times 10^{-5} \mathrm{M}$.

\section{Circular dichroism spectroscopy}

Circular dichroism (CD) spectroscopy is a useful tool to diagnose changes in DNA morphology during drug-DNA intercalations, since the positive band due to base stacking and the negative one due to right-handed helicity are quite sensitive to the interaction mode $[32,33]$. The CD spectroscopy of DNA in the presence of the Sm(III)L is shown in Figure 7. The positive band at $276 \mathrm{~nm}$ and negative one at $249 \mathrm{~nm}$ indicate that the DNA remains right-handed. The intensity of both bands is increased relative to that of free DNA. Simple groove binding and electrostatic interaction show little or no perturbation on the base-stacking and helicity bands, while intercalation enhances the intensities of both bands arising from the right-handed $B$ conformation of CT-DNA (CT-DNA is referred to calf thymus DNA.) as observed for the classical intercalator methylene blue [34]. Thus, the CD spectroscopy of the Sm(III)L-DNA 
system shows a intercalation involving $\pi-\pi^{*}$ stacking and stabilization of the right-handed Bform of DNA $[32,34]$.

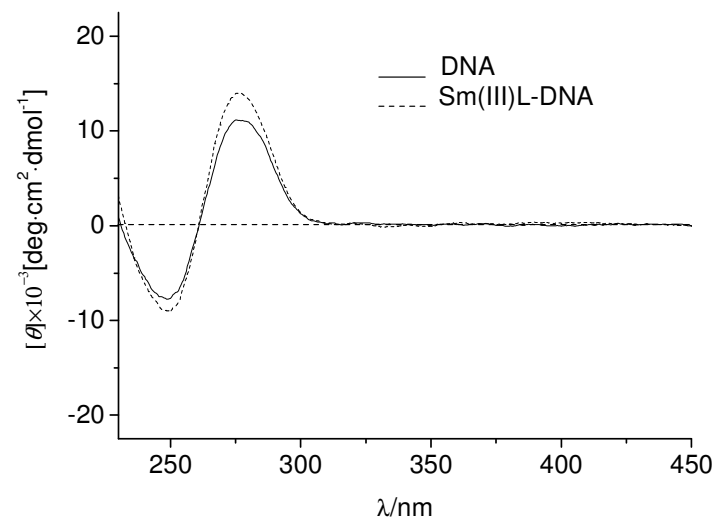

Figure 7. Circular dichroism spectra of DNA in the presence of $\mathrm{Sm}(\mathrm{III}) \mathrm{L} ; c_{\mathrm{DNA}}=1.00 \times 10^{-5} \mathrm{M}$, $\mathrm{c}_{\mathrm{Sm}(\mathrm{III}) \mathrm{L}}=5.00 \times 10^{-5} \mathrm{M}$.

Viscosity measurements

In the absence of crystallographic structural data, hydrodynamic measurements, being sensitive to length change, are regarded as the most critical tests for a binding model in solution [35].

Classical intercalation is known to cause a significant increase in the viscosity of a DNA solution, as the base-pairs are forced away from each other, the double helix unwinds and the DNA lengthens. In contrast, a partial intercalation mode could bend the DNA helix and reduce its effective length and, concomitantly, the viscosity. Non-intercalation binding causes no obvious increase of DNA viscosity $[35,36]$.

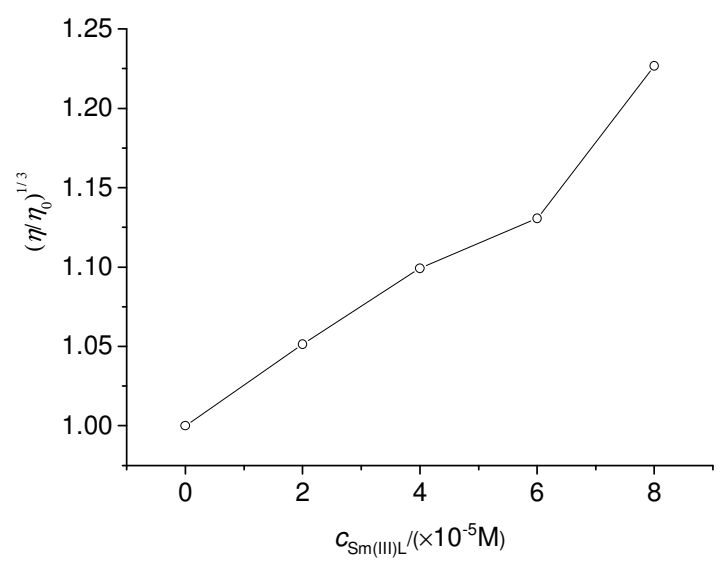

Figure 8 . The effect of increasing amounts of $\mathrm{Sm}(\mathrm{III}) \mathrm{L}$ on the relative viscosities of DNA at 25 ${ }^{\circ} \mathrm{C} ; c_{\mathrm{DNA}}=1.00 \times 10^{-4} \mathrm{M}$. 
The values of $\left(\eta / \eta_{0}\right)^{1 / 3}$ (where $\eta_{0}$ and $\eta$ are the specific viscosity contributions of DNA in the absence and the presence of the $\mathrm{Sm}(\mathrm{III}) \mathrm{L}$, respectively) are plotted against $c_{\mathrm{Sm}(\mathrm{III}) \mathrm{L}}$ in Figure 8 . Addition of $\mathrm{Sm}(\mathrm{III}) \mathrm{L}$ increases the relative specific viscosity of DNA, consistent with lengthening of the DNA double helix by intercalation.

\section{CONCLUSIONS}

The Sm(III) complex of a Schiff base derived from vanillin and L-tryptophan has been synthesized. Its interaction with hsDNA has been studied by UV-Vis absorption, fluorescence, and CD spectroscopy and viscosity methods. The binding constants of Sm(III)L with DNA were measured at 25 and $37^{\circ} \mathrm{C}$, and the thermodynamic parameters were calculated. From a variety of experiments, it is suggested that $\mathrm{Sm}(\mathrm{III}) \mathrm{L}$ can bind to DNA mainly through intercalation but with some groove binding. The binding studied here will provide information helpful to the understanding of the mechanism of interaction of small molecules with nucleic acids and should be useful in the development of new drugs and DNA probes.

\section{ACKNOWLEDGEMENTS}

The authors would like to thank the National Natural Science Foundation of China (NO. 30572254) and Technology and the apparatus support of the Analytical and Testing Center of Southwest University of Science and Technology, China.

\section{REFERENCES}

1. Vaidyanathan, V.G.; Weyhermuller T.; Nair, B.U.; Subramanian, J. J. Inorg. Biochem. 2005, 99, 2248.

2. Song, Y.M.; Wu, Q.; Yang, P.J.; Luan, N.N.; Wang, L.F.; Liu, Y.M. J. Inorg. Biochem. 2006, 100, 1685.

3. Pasternack, R.F.; Gibbs, E.J.; Villafranca, J.J. Biochemistry 1983, 22, 2406.

4. Erkkila, K.E.; Odom, D.T.; Barton, J.K. Chem. Rev. 1999, 99, 2777.

5. Strekowski, L.; Wilson, B. Mutat. Res., Fundam. Mol. Mech. Mutagen. 2007, 623, 3.

6. Schiff, H. Ann. Chem. Pharm. Suppl. 1864, 3, 343.

7. Kopf-Maier, P.; Kopf, H. Chem. Rev. 1987, 87, 1137.

8. Hodnett, E.M.; Mooney, P.D. J. Med. Chem. 1970, 13, 786.

9. Yang, Z.Y.; Wang, B.D.; Li, Y.H. J. Organomet. Chem. 2006, 691, 4159.

10. Zhang, X.Q.; He, Y.; Ding, M. J. Chromatogr. B 2009, 877, 1678.

11. He, X.Q.; Lin, Q.Y.; Hu, R.D.; Lu, X.H. Spectrochim. Acta, Part A 2007, 68, 184.

12. Zhang, Y.; Wang, X.M.; Ding, L.S. J. Serb. Chem. Soc. 2010, 75, 1191.

13. Zhong, W.Y.; Yu, J.S.; Huang, W.L.; Ni, K.Y.; Liang, Y.Q. Biopolymers 2001, 62, 315.

14. Sivasankaran Nair, M.; Selwin Joseyphus, R. Spectrochim. Acta A 2008, 70, 749.

15. Yoe, J.H.; Joens, A.L. Ind. Eng. Chem. (Anal. Ed.) 1944, 16, 111.

16. Nakamoto, K. Infrared and Raman Spectra of Inorganic and Coordination Compounds, 4th ed., John Wiley and Sons: New York; 1986; p 272.

17. Deacon, G.B.; Phillips, R.J. Coord. Chem. Rev. 1980, 33, 227.

18. Mohamed, G.G.; Wahab, Z.H.A.E. Spectrochim. Acta A 2005, 61, 1059.

19. Mohamed, G.G.; Omar, M.M.; Hindy, A.M.M. Spectrochim. Acta A 2005, 62, 1140.

20. Köksal, H.; Tümer, M.; Seria, S. Synth. React. Inorg. Met. Org. Chem. 1996, 26, 1577. 
21. Pyle, A.M.; Rehmann, J.P.; Meshoyrer, R.; Kumar, C.V.; Turro, N.J.; Barton, J.K. J. Am. Chem. Soc. 1989, 111, 3051.

22. Ouameur, A.A.; Marty, R.; Tajmir-Riahi, H.A. Biopolymers 2005, 77, 129.

23. Purcell, M.; Neault, J.F.; Riahi, T. Biochem. Biophys. Acta 2000, 1478, 61.

24. Zhang, G.W.; Guo, J.B.; Pan, J.H.; Chen, X.X.; Wang, J.J. J. Mole. Struct. 2009, 923, 114.

25. Sun, Y.T.; Bi, S.Y.; Song, D.Q.; Qiao, C.Y.; Mu, D.; Zhang, H.Q. Sens. Actuators B: Chem. 2008, 129, 799.

26. Shahabadi, N.; Kashanian, S.; Purfoulad, M. Spectrochim. Acta A 2009, $72,757$.

27. Jing, B.W.; Zhang, M.H.; Shen, T. Spectrochim. Acta A 2004, 60, 2635.

28. Ware, W.R. J. Phys. Chem. 1962, 66, 455.

29. Scatchard, G. Ann. N. Y. Acad. Sci. 1949, 51, 660.

30. Jin, L.; Yang, P.; Li, Q.S. Chem. J. Chin. Uni. 1996, 17, 1345.

31. Tabassum, S.; Parveen, S.; Arjmand, F. Acta Biomater. 2005, 1, 677.

32. Uma Maheswari, P.; Palaniandavar, M. J. Inorg. Biochem. 2004, 98, 219.

33. Ivanov, V.F.; Minchenkova, L.E.; Schyolkina, A.K.; Poletayer, A.I. Biopolymers 1973, 12, 89.

34. Nordén, B.; Tjerneld, F. Biopolymers 1982, 21, 1713.

35. Satyanarayana, S.; Dabrowiak, J.C.; Chaires, J.B. Biochemistry 1992, 31, 9319.

36. Satyanarayana, S.; Dabrowiak, J.C.; Chaires, J.B. Biochemistry 1993, 32, 2573. 